\title{
The Role of Chewing Gum on Post-operative Bowel Recovery after Gynecological Laparoscopic Surgery: A Short Report and Updated Review
}

\author{
Nicko Pisceski Kusika ${ }^{1,2 *}$, Imelda E. B. Hutagaol ${ }^{2}$, Muhammad Yusuf ${ }^{1}$, Suyanto Suyanto ${ }^{3}$, Shinta Puja Tilusari ${ }^{1,2}$ \\ ${ }^{1}$ Department of Obstetrics and Gynecology, Arifin Achmad Hospital, Pekanbaru, Riau, Indonesia; ${ }^{2}$ Department of Obstetrics \\ and Gynecology, Faculty of Medicine, Universitas Riau, Pekanbaru, Riau, Indonesia; ${ }^{3}$ Department of Public Health, Faculty of \\ Medicine, University of Riau, Pekanbaru, Riau, Indonesia
}

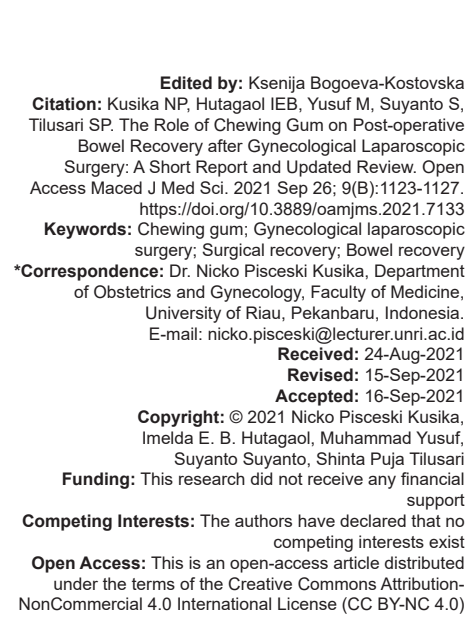

Introduction

Patients are undergoing abdominal surgery experience a reduction of gastrointestinal peristalsis, delaying the routine defecation that lasts for 3-5 days [1], [2]. This common abdominal surgery complication, post-operative ileus (POI), has been reported to be a notable economic burden [3], even equal to that of serious complications [4]. In fact, $\mathrm{POI}$ is responsible for the cost of 1.46 billion USD annually for prolonged hospitalization in the US [5]. Longer hospitalization due to POI may also increase the risk of infection [6]. Even worse, POI may induce the development of deep vein thrombosis, myocardial infarction, and sepsis [7]. Therefore, a multimodal approach has been developed to hasten the recovery through a series of Enhanced Recovery after Surgery (ERAS) protocols [8], [9].

ERAS has introduced a measure of early feeding after the surgery to stimulate bowel motility as an effort to reduce POI [10], [11]. Nonetheless, an earlier report revealed that $27 \%$ of the total patients could not tolerate the early feeding, leading to nausea and vomiting [12]. In the 1800s, the concept of sham feeding was introduced to mimic normal feeding, which can stimulate bowel movement through the parasympathetic nervous system [13]. It is ascribed to images and sensations of foods that increase the vagal nerve-induced gastrointestinal hormones [14]. Similar responses have been observed in sham feeding using chewing gum, where saliva, gastrin, and pancreatic juices are secreted [15], [16], and gastrointestinal tract was stimulated [17], [18]. Hence, chewing gum can be used as a sham feeding to prevent prolonged POI.

Some studies have reported the accelerated intestinal function recovery for patients treated with chewing gum after gynecological surgery [19], [20], [21]. Furthermore, chewing gum may reduce the level of post-operative pain and analgesic requirement [22], [23], [24], [25]. Nevertheless, these results are inconclusive between studies, where a 
study in China showed a null result [26]. A multicenter randomized clinical trial (RCT) also reported the insignificance of chewing gum following abdominal surgery [27]. Systematic review and meta-analysis studies revealed that chewing gum after colorectal [28] and gynecological surgeries [29], [30] improves POI complications. Those reviews agreed that more RCTs are required to clarify the role of chewing gum in the recovery of intestinal function after surgery. This study sought to assess the role of chewing gum on post-operative bowel recovery after gynecological laparoscopic surgery.

\section{Methods}

\section{Study design}

A prospective trial was conducted at a referral hospital, Arifin Achmad Hospital, Riau Province, Indonesia, from January to April 2021. Before the study, all patients were asked for written informed consent, and the ethical clearance had been approved by the Review Ethic Committee of RSUD Arifin Achmad (01/2021). A total of 60 women, aged 23-42 years old and receiving gynecological laparoscopic surgery under general anesthesia, participated in this study following the previously described procedure [1]. The participants were divided equally into intervention groups (gum) and control groups. In the intervention group, the patients were asked to chew sugar-free gum 5 times with $2 \mathrm{~h}$ intervals right after the surgery for $15 \mathrm{~min}$. In the control group, the patients received normal postoperative treatment. Patients with a loose tooth (or teeth) or chronic obstipation were excluded. Patients who underwent the surgery for more than $3 \mathrm{~h}$ or underwent laparotomy were excluded from the study.

\section{Data collection}

Patients' characteristics were collected from the interview and medical record. The time of the first flatus and time of the first bowel sounds were assessed every $2 \mathrm{~h}$. The first passage of flatus was noted by asking the patients, and bowel sounds were detected using a stethoscope. The detected flatus or bowel sounds were denoted as positive mark $(+)$, and the absence was denoted as negative marks $(-)$. The endpoint of this research was up to the fifth $2 \mathrm{~h}$ after the surgery as recommended by the previous studies [26], [31], [32], [33], [34].

\section{Statistical analysis}

The normality of the data was assessed using Kolmogorov-Smirnov. The first passage of flatus and the length of the stay in the hospital was compared between two groups (treatment and control) using Mann-Whitney test since the data were not normally distributed.

\section{Search and selection strategies of literature of the literature review}

To provide more robust data, a literature review was conducted. The online search was conducted in May 2021 using PubMed and Scopus databases using the following terms combination: ((laparoscopic) OR (laparoscopy)) AND ((chewing) OR (gum)) AND (surgery) AND ((gynecological) OR (gynecological) OR (gynecologic) OR (gynecological)). Only literature reporting a $\mathrm{RCT}$ of chewing gum after the gynecological laparoscopic surgery with full access was included in the study. Clinical trials involving laparotomy and cesarean section were excluded from the study. All articles published between January 1950 and May 2021 were eligible.

\section{Results}

The subjects' characteristics of this study are presented in Table 1. Patients in the intervention group had an age range of 23-44 years old, a similar range to the control group (21-42 years old). Similarities between groups were also obtained in the duration of surgery and length of hospitalization. Patients received different surgical procedures depending on their respective gynecological conditions.

Table 1: Characteristics of women participated in the study

\begin{tabular}{lll}
\hline Characteristics & Gum $(\mathrm{n}=30)$ & Control $(\mathrm{n}=30)$ \\
\hline $\begin{array}{c}\text { Age (range, year) } \\
\begin{array}{c}\text { Cases in laparoscopy } \\
\text { Leiomyoma uteri }\end{array}\end{array}$ & $23-44-42$ \\
$\begin{array}{l}\text { Endometriosis cyst } \\
\text { Ovarian cyst }\end{array}$ & $\begin{array}{l}\text { Laparoscopy and hysteroscopy } \\
\text { Laparoscopy and cystectomy }\end{array}$ & $\begin{array}{l}\text { Laparoscopy and hysteroscopy } \\
\text { Laparoscopy and cystectomy }\end{array}$ \\
& $\begin{array}{l}\text { Laparoscopy and cystectomy } \\
\text { the polyp }\end{array}$ & $\begin{array}{l}\text { Hysteroscopic resection of } \\
\text { the polyp }\end{array}$ \\
\hline & &
\end{tabular}

The clinical outcomes from intervention and control groups are presented in Table 2. The time to first flatus and time to first bowel sounds were observed $8 \mathrm{~h}$ after the surgery in the intervention group. However, the flatus and bowel sounds were not detected in the control group, even at the endpoint of the trial. These findings suggest the role of chewing gum in accelerating the onset of flatus passage and bowel motility after gynecological surgery.

Table 2: Comparation of the outcomes between treatment and control groups

\begin{tabular}{lllc}
\hline Characteristics & Gum $(\mathrm{n}=30)$, hour & Control $(\mathrm{n}=30)$, hour & $\mathrm{p}$-value \\
\hline $\begin{array}{l}\text { Duration of surgery, mean } \\
\text { Hospitalization length, }\end{array}$ & 2.5 & 2.5 & $>0.05$ \\
$\begin{array}{l}\text { mean (min-max) } \\
\begin{array}{l}\text { Flatus occurrence, } \\
\text { mean (min-max) }\end{array}\end{array}$ & 15.50 (range: 48-48) & 45.50 (range: 72-72) & $<0.001$ \\
\hline
\end{tabular}


The clinical outcomes from intervention and control groups are presented in Table 3. The time to first flatus and time to first bowel sounds were observed $8 \mathrm{~h}$ after the surgery in intervention group. However, the flatus and bowel sounds were not detected in control group, even at the end point of the trial. These findings suggest the role of chewing gum in accelerating the onset of flatus passage and bowel motility after gynecological surgery.

Table 3: Chewing gum effect on the post-operative clinical outcome

\begin{tabular}{|c|c|c|c|c|c|c|c|c|c|c|}
\hline \multirow[t]{3}{*}{ Group } & \multicolumn{10}{|c|}{ Clinical outcomes observed with $2 \mathrm{~h}$ interval } \\
\hline & \multicolumn{5}{|c|}{ Flatus occurrence } & \multicolumn{5}{|c|}{ Bowel movement } \\
\hline & $1^{\text {st }}$ & $2^{\text {nd }}$ & $3^{\text {rd }}$ & $4^{\text {th }}$ & $5^{\text {th }}$ & $1^{\text {st }}$ & $2^{\text {nd }}$ & $3^{\text {rd }}$ & $4^{\text {th }}$ & $5^{\text {th }}$ \\
\hline Gum $(n=30)$ & - & - & - & + & + & - & - & - & + & + \\
\hline Control $(n=30)$ & _- & - & _- & _ & _- & _- & _- & - & - & - \\
\hline
\end{tabular}

\section{Discussion}

The implementation of ERAS protocol has been proven to lower the economic burden of hospitalization associated with prolonged POI [35]. As a part of ERAS protocol, sham feeding through chewing gum has been studied in multiple RCTs to prevent the prolonged POI [19], [20], [21], [36], [37]. These trials were initiated by a research group led by Asao in 2002 [38], who was motivated by early post-operative oral feeding [10], [11]. Most of the RCTs found that chewing gum improved the gastrointestinal recovery rate. Similar with the findings of those studies, our present study found that the flatus occurrence and bowel sounds were detected earlier in patients in intervention group with chewing gum than those in control group. A study found that the stimulation of bowel motility in those with chewing gum was associated with cephalic-vagal stimulation [39].

A recent systematic review of chewing gum after gynecological surgeries was published in 2018, extracting the data from 10 RCTs; eight studies of laparotomy and two studies of laparoscopy [29]. As of May 2021, we have recorded two additional clinical trials for chewing gum as post-operative treatment in gynecological laparoscopy [1], [25], as presented in Table 4. Those studies revealed that chewing gum increased the recovery time of gastrointestinal function. The most common outcomes with statistical significance were time to first flatus and time to the first defecation.

A study in China with a wide range of laparoscopic surgeries revealed significantly shorter the first passage of flatus or first defecation in intervention group than that in control group [40]. Indication of postoperative pain level reduction was shown by studies conducted in Turkey [25] and Austria [32]. However, none of the included studies reported the reduction in hospital stay duration, which is considered as the primary outcome.
Table 4: Clinical outcomes of chewing gum following gynecological laparoscopic surgery from studies

\begin{tabular}{|c|c|c|c|c|c|}
\hline Year & Country & $\begin{array}{l}\text { Samples } \\
\text { (gum/control) }\end{array}$ & Surgical procedures & $\begin{array}{l}\text { Improved } \\
\text { outcomes }\end{array}$ & Reference \\
\hline 2018 & India & $50 / 51$ & $\begin{array}{l}\text { - Total laparoscopic } \\
\text { hysterectomy } \\
\text { - Medical Termination of } \\
\text { Pregnancy } \\
\text { - Salpingophorectomy or } \\
\text { salpingectomy } \\
\text { - Diagnostic } \\
\text { hysterolaparoscopy }\end{array}$ & $\begin{array}{l}\text { Time to first } \\
\text { flatus, time } \\
\text { to first bowel } \\
\text { sound }\end{array}$ & [1] \\
\hline 2019 & Turkey & $58 / 51$ & $\begin{array}{l}\text { - Laparoscopic } \\
\text { hysterectomy }\end{array}$ & $\begin{array}{l}\text { Time to first } \\
\text { flatus, time to } \\
\text { first defecation, } \\
\text { time to first } \\
\text { bowel sound, } \\
\text { postoperative } \\
\text { pain level }\end{array}$ & [25] \\
\hline 2015 & China & $53 / 56$ & $\begin{array}{l}\text { - Minor to major } \\
\text { laparoscopic surgeries }\end{array}$ & $\begin{array}{l}\text { Time to first } \\
\text { flatus, time } \\
\text { to first bowel } \\
\text { sounds }\end{array}$ & [40] \\
\hline 2013 & Austria & $85 / 94$ & $\begin{array}{l}\text { - Salpingophorectomy or } \\
\text { salpingectomy } \\
\text { - Salpingophorectomy } \\
\text { Total laparoscopic } \\
\text { hysterectomy } \\
\text { - Myomectomy } \\
\text { - Ovarian cystectomy } \\
\text { - Diagnostic laparoscopy }\end{array}$ & $\begin{array}{l}\text { Time to first } \\
\text { flatus, time } \\
\text { to first bowel } \\
\text { sound, and } \\
\text { opioid analgetic } \\
\text { requirement }\end{array}$ & [32] \\
\hline
\end{tabular}

In conclusive results obtained by the previous studies could be attributed to the heterogeneity in the type of surgery undergone by the patients [28]. Another heterogeneity factor affecting the clinical trial's outcome is the patients' characteristics, such as body mass index and age. Patients with higher body mass index and older age could have increased levels of risk in developing POI. Therefore, studies with different surgical approaches and patient populations could yield different results. Only one study performed the analysis in quartiles based on the body mass index and age of the patients [25]. In comparison to others, the aforementioned study had a significance because they were the first to report the results of chewing gum after total laparoscopic hysterectomy, where chewing gum significantly shortened the time to first defecation and lowered the level of post-operative pain [25]. Other than heterogeneity, the number of participants may also affect the trial's final outcome [27].

There are some limitations of this study. The study had a relatively small number of patients. Besides, the first flatus times were measured in periodic time with long ranges.

\section{Conclusion}

Sham feeding by means of chewing gum following the gynecological laparoscopic surgery accelerates the recovery of gastrointestinal functions. More robust RCTs are necessary to reach a conclusive result. 


\section{References}

1. Bhatiyani B, Pandeeswari, Bhasani D, Dhumale S. Effect of chewing gum on the postoperative recovery of gastrointestinal function after gynaecological laparoscopic surgery. Int J Reprod Contracept Obstet Gynecol. 2018;7(2):187. https://doi. org/10.18203/2320-1770.ijrcog20180187

2. Manisha, Duhan N. Impact of gum chewing on recovery of bowel activity after caesarean section. Int J Reprod Contracept Obstet Gynecol. 2020;9(3):888. https://doi.org/10.18203/23201770.jircog20200888

3. Iyer S, Saunders WB, Stemkowski S. Economic burden of postoperative ileus associated with colectomy in the United States. J Manag Care Pharm. 2009;15(6):485-94. https://doi. org/10.18553/jmcp.2009.15.6.485

PMid:19610681

4. Asgeirsson $\mathrm{T}$, El-Badawi $\mathrm{Kl}$, Mahmood A, Barletta J, Luchtefeld M, Senagore AJ. Postoperative ileus: It costs more than you expect. J Am Coll Surg. 2010;210(2):228-31. https:// doi.org/10.1016/j.jamcollsurg.2009.09.028

PMid:20113944

5. Goldstein JL, Matuszewski KA, Delaney CP, Senagore A, Chiao EF, Shah $\mathrm{M}$, et al. Inpatient economic burden of postoperative ileus associated with abdominal surgery in the United States. P T. 2007;32(2):82-90.

6. Lubawski J, Saclarides T. Postoperative ileus: Strategies for reduction. Ther Clin Risk Manage. 2008;4(5):913-7.

PMid:19209273

7. Swong K, Johans S, Molefe A, Hofler RC, Wemhoff M, Kuo P, et al. Unintended consequences after postoperative ileus in spinal fusion patients. World Neurosurg. 2019;122:e512-5. https://doi.org/10.1016/j.wneu.2018.10.093

PMid:31060199

8. Nelson G, Altman AD, Nick A, Meyer LA, Ramirez PT, Achtari C et al. Guidelines for postoperative care in gynecologic/oncology surgery: Enhanced recovery after surgery (ERAS(R)) society recommendations-part II. Gynecol Oncol. 2016;140(2):323-32. https://doi.org/10.1016/j.ygyno.2015.12.019

PMid:26757238

9. Maessen JM, Dejong CH, Kessels AG, von Meyenfeldt MF, Enhanced Recovery After Surgery Group. Length of stay: An inappropriate readout of the success of enhanced recovery programs. World J Surg. 2008;32(6):971-5. https://doi. org/10.1007/s00268-007-9404-9

PMid: 18224480

10. Watters JM, Kirkpatrick SM, Norris SB, Shamji FM, Wells GA. Immediate postoperative enteral feeding results in impaired respiratory mechanics and decreased mobility. Ann Surg. 1997;226(3):369-77. https://doi. org/10.1097/00000658-199709000-00016

PMid:9339943

11. Reissman $P$, Teoh TA, Cohen SM, Weiss EG, Nogueras JJ, Wexner SD. Is early oral feeding safe after elective colorectal surgery? A prospective randomized trial. Ann Surg. 1995;222(1):73-7. https://doi. org/10.1097/00000658-199507000-00012

PMid:7618972

12. Petrelli NJ, Cheng C, Driscoll D, Rodriguez-Bigas MA. Early postoperative oral feeding after colectomy: An analysis of factors that may predict failure. Ann Surg Oncol. 2001;8(10):796-800. https://doi.org/10.1007/s10434-001-0796-8 PMid:11776493

13. Stern RM, Crawford HE, Stewart WR, Vasey MW, Koch KL. Sham feeding. Cephalic-vagal influences on gastric myoelectric activity. Dig Dis Sci. 1989;34(4):521-7. https://doi.org/10.1007/ bf01536327

\section{PMid:2702882}

14. Feldman M, Richardson CT. Role of thought, sight, smell, and taste of food in the cephalic phase of gastric acid secretion in humans. Gastroenterology. 1986;90(2):428-33. https://doi. org/10.1016/0016-5085(86)90943-1

\section{PMid:3940915}

15. Wojdemann M, Wettergren A, Hartmann B, Hilsted L, Holst JJ. Inhibition of sham feeding-stimulated human gastric acid secretion by glucagon-like peptide-2. J Clin Endocrinol Metab. 1999;84(7):2513-7. https://doi.org/10.1210/jcem.84.7.5840

16. Konturek SJ, Thor P. Relation between duodenal alkaline secretion and motility in fasted and sham-fed dogs. Am J Physiol. 1986;251(5):G591-6. https://doi.org/10.1152/ ajpgi.1986.251.5.g591

17. Jepsen JM, Skoubo-Kristensen E, Elsborg L. Rectosigmoid motility response to sham feeding in irritable bowel syndrome. Evidence of a cephalic phase. Scand J Gastroenterol. 1989;24(1):53-6. https://doi.org/10.3109/00365528909092239 PMid:2928723

18. Huge A, Kreis ME, Zittel TT, Becker HD, Starlinger MJ, Jehle EC. Postoperative colonic motility and tone in patients after colorectal surgery. Dis Colon Rectum. 2000;43(7):932-9. https://doi.org/10.1007/bf02237353

PMid:10910238

19. Abd-El-Maeboud KH, Ibrahim MI, Shalaby DA, Fikry MF. Gum chewing stimulates early return of bowel motility after caesarean section. BJOG. 2009;116(10):1334-9. https://doi. org/10.1111/j.1471-0528.2009.02225.x

PMid:20002378

20. Pereira Gomes Morais E, Riera R, Porfirio GJ, Macedo CR, Sarmento Vasconcelos $\mathrm{V}$, de Souza Pedrosa $\mathrm{A}$, et al. Chewing gum for enhancing early recovery of bowel function after caesarean section. Cochrane Database Syst Rev. 2016;10:CD011562. https://doi.org/10.1002/14651858. cd011562.pub2 PMid:27747876

21. Shabaan $M$, Dieb $A$. The role of gum chewing in regaining bowel motility in patients undergoing cesarean section: A randomized controlled trial. Evid Based Womens Health J. 2019;9(4):568-73. https://doi.org/10.21608/ebwhj.2019.64360

22. Byrne CM, Zahid A, Young JM, Solomon MJ, Young CJ. Gum chewing aids bowel function return and analgesic requirements after bowel surgery: A randomized controlled trial. Colorectal Dis. 2018;20(5):438-48. https://doi.org/10.1111/codi.14041 PMid:29053219

23. Urcanoglu OB, Yildiz T. Effects of gum chewing on early postoperative recovery after laparoscopic cholecystectomy surgery: A randomized controlled trial. Indian J Surg. 2020;83:1203-9. https://doi.org/10.1007/s12262-020-02628-7

24. Esfehani RJ, Yazd MM, Rsfehani AJ, Foji S, Kamalimanesh B. Effect of chewing gum on post cesarean ileus in the North East of Iran: A randomized clinical trial. J Midwif Reprod Health. 2018;6(3):1357-64.

25. Turkay U, Yavuz A, Hortu I, Terzi H, Kale A. The impact of chewing gum on postoperative bowel activity and postoperative pain after total laparoscopic hysterectomy. J Obstet Gynaecol. 2020;40(5):705-9.

PMid:31609137

26. Ge B, Zhao H, Lin R, Wang J, Chen Q, Liu L, et al. Influence of gum-chewing on postoperative bowel activity after laparoscopic surgery for gastric cancer: A randomized controlled trial. Medicine (Baltimore). 2017;96(13):e6501. https://doi. org/10.1097/md.0000000000006501 


\section{PMid:28353600}

27. de Leede EM, van Leersum NJ, Kroon HM, van Weel V, van der Sijp JR, Bonsing BA, et al. Multicentre randomized clinical trial of the effect of chewing gum after abdominal surgery. Br J Surg. 2018;105(7):820-8. https://doi.org/10.1002/bjs.10828 PMid:29469944

28. Mei B, Wang W, Cui F, Wen Z, Shen M. Chewing gum for intestinal function recovery after colorectal cancer surgery: A systematic review and meta-analysis. Gastroenterol Res Pract. 2017;2017:3087904. https://doi.org/10.1155/2017/3087904 PMid:29312450

29. Xu C, Peng J, Liu S, Qi DY. Effect of chewing gum on gastrointestinal function after gynecological surgery: A systematic literature review and meta-analysis. J Obstet Gynaecol Res. 2018;44(5):936-43. https://doi.org/10.1111/ jog. 13602 PMid:29442412

30. Wen Z, Shen M, Wu C, Ding J, Mei B. Chewing gum for intestinal function recovery after caesarean section: A systematic review and meta-analysis. BMC Pregnancy Childbirth. 2017:17(1):105. https://doi.org/10.1186/s12884-017-1286-8

PMid:28415967

31. Farouk D, Mutlag SA, Youssef D. The relation between gum chewing in early post-operative period and the return of gastrointestinal function after caesarean section. Obstet Gynecol Int J. 2019;10(6):475. https://doi.org/10.15406/ogij.2019.10.00475

32. Husslein H, Franz M, Gutschi M, Worda C, Polterauer S, Leipold H. Postoperative gum chewing after gynecologic laparoscopic surgery: A randomized controlled trial. Obstet Gynecol. 2013;122(1):85-90. https://doi.org/10.1097/ aog.0b013e3182983e92

33. Atkinson C, Penfold CM, Ness AR, Longman RJ, Thomas SJ, Hollingworth W, et al. Randomized clinical trial of postoperative chewing gum versus standard care after colorectal resection. $\mathrm{Br}$ J Surg. 2016;103(8):962-70. https://doi.org/10.1002/bjs.10194 PMid:27146793

34. Roslan F, Kushairi A, Cappuyns L, Daliya P, Adiamah A. The impact of sham feeding with chewing gum on postoperative ileus following colorectal surgery: A meta-analysis of randomised controlled trials. J Gastrointest Surg. 2020;24(11):2643-53. https://doi.org/10.1007/s11605-019-04507-3

PMid:32103455

35. Noba L, Rodgers S, Chandler C, Balfour A, Hariharan D, Yip VS Enhanced recovery after surgery (ERAS) reduces hospital costs and improve clinical outcomes in liver surgery: Asystematic review and meta-analysis. J Gastrointest Surg. 2020;24(4):918-32. https://doi.org/10.1007/s11605-019-04499-0

PMid:31900738

36. Yenigul NN, Aydogan Mathyk B, Aslan Cetin B, Yazici Yilmaz F, Ayhan I. Efficacy of chewing gum for improving bowel function after cesarean sections: A randomized controlled trial. J Matern Fetal Neonatal Med. 2020;33(11):1840-5. https://doi.org/10.108 $0 / 14767058.2018 .1531122$ PMid:30606082

37. Nanthiphatthanachai A, Insin P. Effect of chewing gum on gastrointestinal function recovery after surgery of gynecological cancer patients at Rajavithi hospital: A randomized controlled trial. Asian Pac J Cancer Prev. 2020;21(3):761-70. https://doi. org/10.31557/apjcp.2020.21.3.761 PMid:32212805

38. Asao T, Kuwano H, Nakamura J, Morinaga N, Hirayama I, Ide M. Gum chewing enhances early recovery from postoperative ileus after laparoscopic colectomy. J Am Coll Surg. 2002;195(1):30-2. https://doi.org/10.1016/s1072-7515(02)01179-1

PMid:12113542

39. Richardson CT, Walsh JH, Cooper KA, Feldman M, Fordtran JS Studies on the role of cephalic-vagal stimulation in the acid secretory response to eating in normal human subjects. J Clin Invest. 1977;60(2):435-41. https://doi.org/10.1172/jci108793 PMid:874101

40. Gong Y, Zhang Q, Qiao L, Lv D, Ruan J, Chen H, et al. Xylito gum chewing to achieve early postoperative restoration of bowel motility after laparoscopic surgery. Surg Laparosc Endosc Percutan Tech. 2015;25(4):303-6. https://doi.org/10.1097/ sle. 0000000000000174

PMid:26121546 